\title{
Potential assessment of using dry cooling mode in two different solar thermal power plants
}

\author{
T.E. Boukelia ${ }^{1}$, M.S. Mecibah ${ }^{2}$, A. Laouafi ${ }^{3}$, A. Mekroud ${ }^{4}$, A.Bouraoui $^{1}$ \\ ${ }^{1}$ Laboratory of Applied Energetics and Materials, Mechanical Department, Jijel University, ALGERIA \\ ${ }^{2}$ Laboratory of Mechanics, Mechanical Department, University of Brothers Mentouri, Constantine 25000, ALGERIA \\ ${ }^{3}$ Department of Electrical Engineering, University of 20 August 1955-Skikda, Skikda, ALGERIA \\ ${ }^{4}$ Laboratory of Renewable Energies and Durable Development, Mechanical Department, University of Brothers Mentouri, \\ Constantine 25000, ALGERIA \\ taqy25000@hotmail.com
}

\begin{abstract}
Most of Concentrating Solar Power (CSP) plants are usually installed in desert regions where water resource availability is a critical limitation due to the lack of water required for the exploitation of these systems in these regions. Therefore, the aim of this study is to investigate the techno-economic competitiveness of deploying both modes of cooling (wet and dry) in two different parabolic trough solar thermal power plants integrated with thermal energy storage and fuel backup system; the first one is using thermic oil, while the other is working using molten salt. The obtained results show that the dry cooling mode can decrease the yields of the two power plants down to $8.7 \%$ and $9.3 \%$ for oil and salt configurations respectively. On the other hand, the levelized cost of electricity can increase by using this cooling option up to $9.3 \%$ for oil plant, and $10.0 \%$ for salt one. However, the main advantage of using dry cooling option is reducing water consumption which has been decreased by more than $94 \%$ for both plants. The application of our methodology to other two sites worldwide, confirms the viability of the obtained results. The importance of this result is to show the effect of working fluids on the cooling system of solar power plants.
\end{abstract}

Keywords: Cooling mode; Dry; Parabolic trough solar thermal power plant; Wet. Received: 01/12/2017 - Accepted: 27/12/2017

\section{Introduction}

These With the rising price of fossil fuels, and the elevation of the levels of air pollution and gas emissions, solar energy has the potential to cater the world energy needs with clean and competitive power in the future. Among technologies developed to convert pure solar radiation to useful energy such as heat or electricity, CSP (concentrating solar power) is one of the most promising options for power generation. Most of CSP plants consist of solar field (SF), power block (PB), and optionally thermal energy storage (TES) system or fuel backup system (FBS) can be used for enhancing the system potential and stabilize the grid [1]. The existing CSP plants convert thermal energy collected by the SF in the $\mathrm{PB}$, based on conventional steam Rankine cycle with regeneration.

Many studies in the literature compared different configurations of parabolic trough solar thermal power plants (PTSTPPs) with different working fluids such as steam/water, synthetic oil, and molten salt, to find the best technology with low investment cost and high thermal performances to be adopted in these systems.
For example, Reddy and Kumar [2] performed an investigation to make a techno-economic assessment of a PTSTPP with two different technologies; the first is based on synthetic oil as working fluid in the SF, while the other is a direct steam generation (DSG) plant. In the first step, and in addition to the operating conditions of these two plants, the design including solar field geometry have been optimized. Secondly, the two optimized plants were chosen for the viability study in the Indian climatic conditions. The obtained results show that DSG has a better levelized cost of electricity (LCOE) compared to oil plant. Furthermore, Boukelia et al [3] made a 4E (Energy-Exergy-EconomicEnvironment) comparison between different plants based on synthetic oil and other based on molten salt. They found that molten salt plants have lower LCOE compared to the same configurations based on thermic oil. In another study [4], they found that it is possible to optimize salt plant to give a higher annual power generation and lower LCOE in comparison to oil optimized plant with almost $26 \%$ and $15 \%$ respectively. 
Furthermore, Montes and his team [5] developed a thermofluidynamic model to evaluate energy and exergy SF performances with three primary working fluids: water/steam, thermic oil, and molten solar salt. According to their results, and from the point of view of the energy efficiency of the SF, oil shows better performance compared to the two others. On the other side, solar salt seems to be the best technology in terms of exergy performance. Moreover, a comparative study based on both design and yield has been performed by Giostri et al. [6]. They obtained better performances by using salt plant compared to oil one.

On the other hand, the thermodynamics rules state that wet cooling of conventional steam rankine cycles is advantageous over dry cooling in terms of efficiencies since with wet cooling option the exit steam from the turbine will be cooled down faster and to a lower temperature than with the second option [7]. However, unlike conventional steam power plants, which are generally installed in the coastal regions, where water resource availability is not critical limitation, CSP plants are usually installed in desert regions with semi-arid and arid climate, where there is a lack of water resources. Therefore, it is so important to investigate the technoeconomic competitiveness of deploying dry cooling mode in such systems.

Some studies showed that the integration of dry cooling in solar thermal power plants could save more than $90 \%$ of water consumption; however, the overall performance of such systems will be reduced due to the higher ambient temperatures [7]. Liqreina and Qoaider [7] analyzed the competitiveness of using dry cooling mode in a reference Andasol 1 parabolic trough power plant. Ma'an area (South of Jordan) was taken as a case study. The results proved that by employing dry cooling mode in CSP, the annual power generation has been decreased by more than $11 \%$, the water consumption has also decreased by more than $92 \%$, and this cooling option also increased the LCOE by almost $13 \%$ in comparison to conventional wet cooling mode. Colmenar-Santos et al. [8] highlighted water consumption as one of decisive parameters for the erection of CSP plants. They analyzed different technical alternative options for minimizing water usage, and their effects on these systems were also presented. Furthermore, Martín [9] optimized the operation of CSP plant with dry cooling mode located in Almería (South of Spain) over a year. For this purpose, a multi period mixed integer non-linear mathematical formulation was used to optimize the operating working conditions in both thermal cycles and cooling system. Another study performed by Deng and Boehm [10] reporting the potential performance of dry cooling in trough solar thermal power plants. The commercial Gate-Cycle was used to estimate the technical performances of both wet and dry cooling modes. In this study, Las Vegas (USA) has been considered for the simulation.
Other studies [11-13] investigated the same problem of using dry cooling mode in a solar thermal power plant. However, among studies published in the literature, no comparative study between the influence of using the two modes of cooling (wet and dry) in CSP plants with different working fluids has been conducted. Therefore, the objective of this paper is to investigate the technoeconomic competitiveness of deploying dry cooling mode in two solar thermal power plants considering both hourly and annual basis; the first is based on synthetic oil as primary heat transfer fluid (HTF) in the SF and the other is using molten salt technology. The importance of such a study is to show the techno-economic impact of using the two cooling modes on solar power plants with two different main HTFs. On the other hand, as there is still an open question about the possibility of using molten salt as primary heat transfer working fluid in the plant, this paper gives another decisive parameter that favors the using of molten salts in CSP plants compared to synthetic oils.

\section{Data and methodology}

\section{II.1. Plants configuration}

Nowadays, most of the commercially operated PTSTPPs in the world have a capacity of $50 \mathrm{MWe}$. Thereby, two configurations of large scale CSP plants of 50 MW integrated with TES and FBS, have been selected in this study to perform the techno-economic analysis. The designs of the SF and $\mathrm{PB}$ of the investigated plants have been considered based on existing commercial plants. In order to study these two configurations, similar assumptions such as the size of the plant, components, etc. are imposed, in order to have a common ground for comparison. The difference between these two configurations is the heat transfer fluids (HTF) which has been taken as thermic oil of type Therminol VP-1 in the first configuration with a temperature range of $293-393{ }^{\circ} \mathrm{C}$ at the inlet and outlet of the SF, respectively, and molten solar salt $\left(60 \% \mathrm{NaNO}_{3}+\right.$ $\left.40 \% \mathrm{KNO}_{3}\right)$ in the second one with a temperature range of $\left(286-550^{\circ} \mathrm{C}\right)$.

The SF consists of parabolic trough collector assemblies of Solargenix SGX-1 type. Each solar collector assembly is of $100 \mathrm{~m}$ length, $5 \mathrm{~m}$ of width aperture and consists of 12 modules. Four solar collector assemblies are arranged in a row, along north-south horizontal axis and track the sun from east to west [14]. The two PBs (with oil and salt) of this work are assumed to operate using a steam regenerative Rankine cycle of $50 \mathrm{MW}$. The considered plants are installed in Bechar (latitude $31.38^{\circ} \mathrm{N}$, longitude $2.15^{\circ} \mathrm{W}$, altitude $806 \mathrm{~m}$ ), Algeria, which has been chosen due to its high direct solar irradiation (more than $2500 \mathrm{~kW} \mathrm{~h} / \mathrm{m}^{2}$ ). The two solar thermal plants have been incorporated with TES 
and FBS, and two different cooling options (wet cooling mode with a condenser, and dry one based on air cooled system) were considered. The schematic layout of the two configurations is illustrated in Fig. 1, while the common assumptions and nominal values of the main parameters considered in the two plants are listed in Table 1.
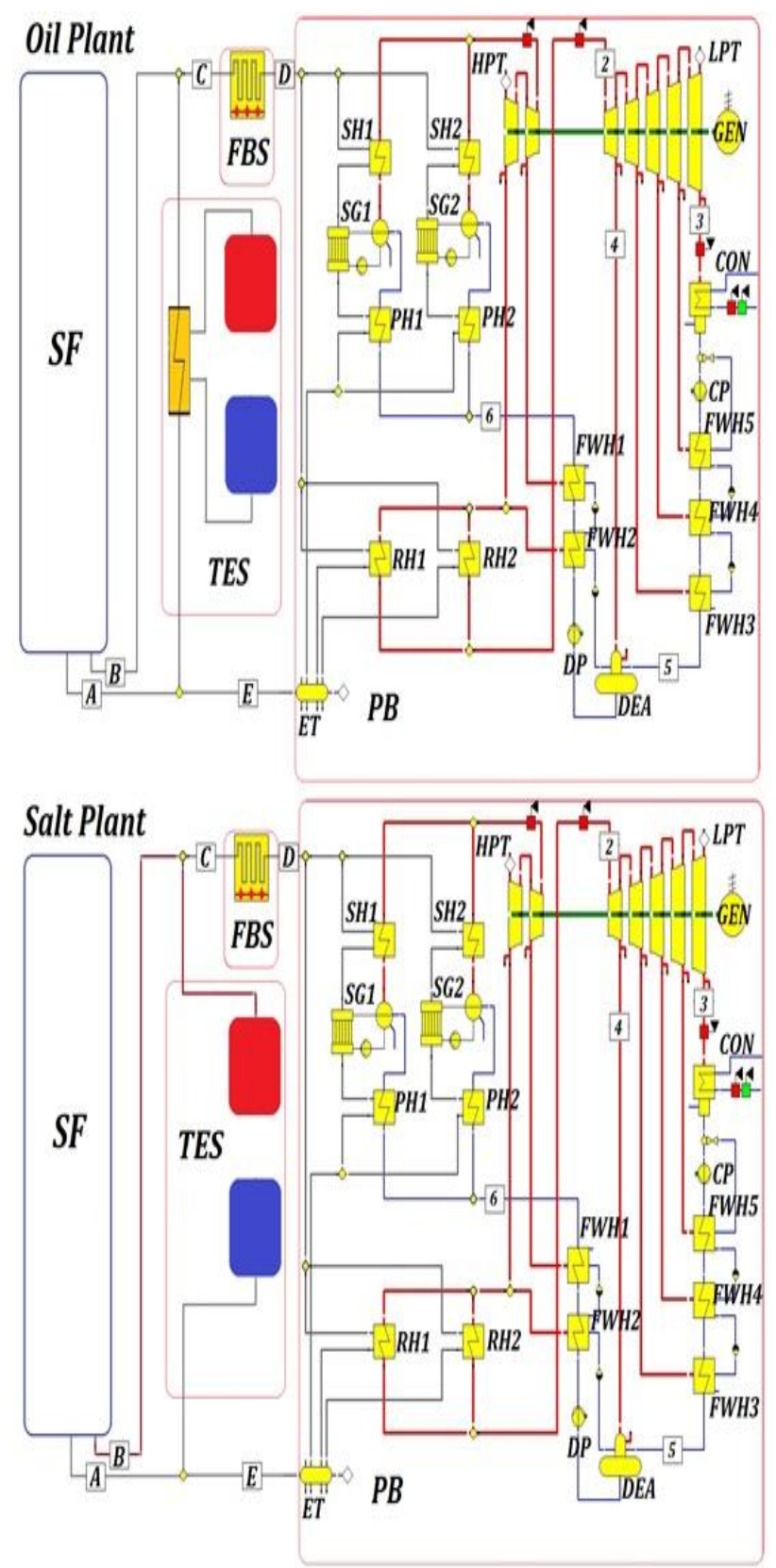

Figure 1. Schematic for the two studied configurations.
Table 1. The main inputs of the two proposed plants

\begin{tabular}{|c|c|c|}
\hline Configuration & Oil plant & Salt plant \\
\hline \multicolumn{3}{|l|}{ Solar Field } \\
\hline - $\quad$ Solar multiple & \multicolumn{2}{|c|}{1.6} \\
\hline Number of loops & 184 & 167 \\
\hline Aperture area $\left(\mathrm{m}^{2}\right)$ & 346,141 & 314,160 \\
\hline - $\quad$ Collector orientation & $\mathrm{N}-\mathrm{S}$ & $\mathrm{N}-\mathrm{S}$ \\
\hline $\begin{array}{ll} & \text { Collector design } \\
\end{array}$ & \multicolumn{2}{|c|}{ Solargenix SGX-1 } \\
\hline - $\quad$ Receiver design & \multicolumn{2}{|c|}{ Schott PTR 70} \\
\hline - $\quad$ Row spacing (m) & \multicolumn{2}{|c|}{15} \\
\hline Thermal Energy Storage & Indirect & Direct \\
\hline - $\quad$ Full load hours (hr) & \multicolumn{2}{|c|}{7.5} \\
\hline - $\quad$ Thermal capacity $\left(\mathrm{kWh}_{\mathrm{t}}\right)$ & $1,107.1$ & 1003.65 \\
\hline - $\quad$ Storage volume $\left(\mathrm{m}^{3}\right)$ & 16,683 & 4,953 \\
\hline \multicolumn{3}{|l|}{ Fuel Backup System } \\
\hline - $\quad$ Outlet set temperature $\left({ }^{\circ} \mathrm{C}\right)$ & 393 & 550 \\
\hline \multicolumn{3}{|l|}{ Power Block } \\
\hline $\begin{array}{l}\bullet \quad \text { Outlet conditions } \\
\checkmark \text { Temperature }\left({ }^{\circ} \mathrm{C}\right) / \text { Pressure (bar) } \\
\checkmark \text { Mass flow rate }(\mathrm{kg} / \mathrm{s}) \\
\end{array}$ & $\begin{array}{c}296 / 15 \\
567.1 \\
\end{array}$ & $\begin{array}{c}286 / 1 \\
303.42 \\
\end{array}$ \\
\hline $\begin{array}{l}\bullet \quad \text { Inlet conditions } \\
\checkmark \text { Temperature }\left({ }^{\circ} \mathrm{C}\right) / \text { Pressure (bar) } \\
\checkmark \text { Mass flow rate }(\mathrm{kg} / \mathrm{s})\end{array}$ & $\begin{array}{c}393 / 20 \\
567.1 \\
\end{array}$ & $\begin{array}{l}550 / 3.7 \\
303.42 \\
\end{array}$ \\
\hline - $\quad$ Net electrical output $\left(\mathrm{MW}_{\mathrm{e}}\right)$ & 50 & 50 \\
\hline
\end{tabular}

\section{II.2. Mathematical modelling}

The techno-economic study based on energy and economic analysis is required to determine the viability of any energy system. In this paper, the free software System Advisor Model (SAM) version 2014.1.14, was used to perform the simulation. The model used in this software was previously validated by Price [15]. The detailed model used in this software is presented by Wagner and Gilman [16]. As the analytical model of the studied plants is quite significant and all the complexities involved in the power plants are considered in the software, the presented mathematical modelling in this work will be limited to the main equations of both energy and economic analyses, while the full detailed model can be found in the literature [16].

\section{II.2.1. Energy analysis}

The total incident solar energy received by SF aperture area is given as:

$$
\phi_{i}=I_{b} \cdot A \cdot \cos \theta
$$

While the total useful energy delivered by the SF is presented as:

$$
\phi_{u}=\dot{m}_{f} \cdot\left(h_{S F 0}-h_{S F i}\right)
$$

Therefore, the energy efficiency of the SF is given as:

$$
\eta_{s F}=\frac{\phi_{u}}{\phi_{i}}
$$

In this paper, the solar multiple (SM) is a key factor which defined as the ratio between thermal power obtained by the SF at design point and thermal power required by the $\mathrm{PB}$ at nominal conditions [17], and expressed as follow:

$$
S M_{\text {design point }}=\frac{\phi_{\text {th SF }}}{\phi_{\text {th } P B}}
$$


The SM was taken as 1.60 for both plants [17-18] to have common ground of comparison to perform technoeconomic analysis.

On the other side, as solar thermal power plants suffer from low dispatch capacity compared to conventional thermal power plants based on fossil fuels, and in order to enhance the potential of the considered plants and to extend their working hours, this issue has been solved in this study by incorporating thermal energy storage and fuel backup system together at the same time to these plants. In this study, the full load hours of the storage defines the number of hours of energy supply for the operation of the PB. It is assumed to be 7.5 equivalent hours at the design point, and can be calculated as follows [16]:

$$
E_{\text {tes }}=\frac{w_{\text {des }} \Delta_{\text {tes }}}{\eta_{\text {cycles des }}}
$$

The main design parameters of the storage systems are presented in Table 2 .

\begin{tabular}{lll}
\hline The plant & Therminol VP1 & Solar salt \\
\hline Type of storage & Indirect & Direct \\
\hline Full load hours of TES $($ hours $)$ & 7.5 & 7.5 \\
\hline TES thermal capacity $(\boldsymbol{M W h})$ & $1,107.09$ & $1,003.65$ \\
\hline Tank high $(\boldsymbol{m})$ & 14 & 14 \\
\hline Tank heater efficiency & 0.98 & 0.98 \\
\hline
\end{tabular}

Table 2.The main parameters of the storage systems at the design point.

Furthermore, the fuel backup system is another component that supplies thermal energy to the working fluid at the inlet of the high pressure turbine whenever the thermodynamical state has not been obtained, while maintaining a total auxiliary contribution less than fossil fill fraction at the same time. This parameter can be defined as [19]:

$$
\begin{aligned}
& \phi_{\text {backup }}=\dot{m}\left(h_{\text {in turbine }}-h_{\text {out }, S F}\right) \\
& f_{\text {bachup }}=\frac{\phi_{\text {bachup }}}{\phi_{\text {tot }}}
\end{aligned}
$$

The energy efficiency of the PB is calculated as:

$$
\eta_{P B}=\frac{P G_{\text {net }}}{\phi_{\text {in }}}
$$

Where $\phi_{\text {in }}$ is the total thermal energy received by the $\mathrm{PB}$, this total thermal energy received by the PB.

The overall energy efficiency of the plant is given as:

$$
\eta_{o}=\eta_{S F} \times \eta_{P B}
$$

While the net capacity factor of the plants is given by:

$$
C F=\frac{P G_{\text {net }}}{N D \cdot\left(24 \frac{h r}{d a y}\right) \cdot 50 M W}
$$

Where:

ND is the number of the days in a year.

To perform this study, two different cooling mode in the power blocks were considered, wet cooling and dry one. The mathematical model of the heat rejection in these plants is presented in detail in the literature [16]. The main inputs for the cooling systems are summarized in Table 3.
Table 3. The main inputs for the two cooling options [16]

\begin{tabular}{lcc}
\hline Type of cooling & $\begin{array}{c}\text { Wet } \\
\text { (Evaporative) }\end{array}$ & $\begin{array}{c}\text { Dry (Air } \\
\text { cooled) }\end{array}$ \\
\hline Ambient temperature at deign $\left({ }^{\circ} \mathrm{C}\right)$ & 20 & 20 \\
\hline $\begin{array}{l}\text { The cooling water temperature rise } \\
\text { across the condenser }\left({ }^{\circ} \mathrm{C}\right)\end{array}$ & 10 & - \\
\hline $\begin{array}{l}\text { Temperature difference at the hot side } \\
\text { of the condenser }\left({ }^{\circ} \mathrm{C}\right)\end{array}$ & 3 & - \\
\hline Circulating water pressure drop $($ bar) & 0.37 & - \\
\hline $\begin{array}{l}\text { Cooling pump } \\
\text { mechanical/isentropic efficiency }\end{array}$ & $0.75 / 0.80$ & - \\
\hline Fan mechanical/isentropic efficiency & $0.75 / 0.80$ & $0.94 / 0.80$ \\
\hline The condenser air pressure ratio & - & 1.0028 \\
\hline
\end{tabular}

\section{II.2.2. Economic analysis}

As the levelized cost of electricity (LCOE) is the major figure to analyze the viability of any solar thermal power plant [20], and this indicator can be significantly affected by assumptions and inputs such as operation and maintenance and investment costs, the economic inputs of this study were set according to previous studies and databases [16, 17, 21]. The economic assessment is performed using the software SAM, where the LCOE is calculated as follows:

$L C O E=\frac{\operatorname{crf} \cdot C_{\text {In }}+C_{\text {osM }}-C_{\text {env }}}{Q_{\text {elNet }}}$

Where,

$$
\operatorname{crf}=\frac{k_{d^{x}}\left(k_{d}+1\right)^{N}}{\left[\left(k_{d}+1\right)^{N}-1\right]}
$$

\section{Results and discussion}

The annual mean hourly water consumption mass flow rates $(\mathrm{kg} / \mathrm{s})$, net electric power outputs $(\mathrm{MWh})$, power cycle efficiency, in addition to annual comparative analysis of using wet and dry cooling modes in the two presented configurations are presented in figures $2,3,4$ and table 4 , respectively.

Table 4. Annual comparative analysis of using wet and dry cooling modes in the two optimized plants.

\begin{tabular}{lcccc}
\hline \multicolumn{7}{c}{ Oet } & Dry & Wet & Dalt plant \\
\hline $\begin{array}{l}\text { Mean energy } \\
\text { efficiency of the } \\
\text { plant }\left(\eta_{0}\right)\end{array}$ & 18.64 & 17.01 & 18.26 & 16.56 \\
\hline $\begin{array}{l}\text { Capacity factor } \\
(\%)\end{array}$ & 38.2 & 34.9 & 34.0 & 30.8 \\
\hline $\begin{array}{l}\text { Annual power } \\
\text { generation }(\mathrm{GWh})\end{array}$ & 165.74 & 151.26 & 147.35 & 133.63 \\
\hline $\begin{array}{l}\text { LCOE } \\
(\text { Cent/kWh) }\end{array}$ & 11.58 & 12.66 & 9.68 & 10.65 \\
\hline $\begin{array}{l}\text { Annual water } \\
\text { consumption }\left(\mathrm{m}^{3}\right)\end{array}$ & 633,635 & 32,765 & 518,329 & 26,319 \\
\hline
\end{tabular}




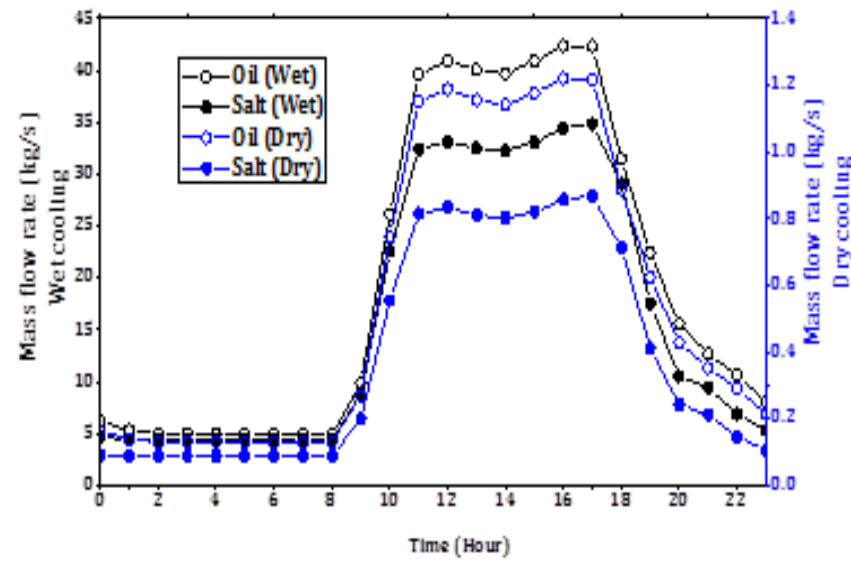

Figure 2. Annual mean hourly water consumption in the two studied plants by using wet and dry cooling modes.

It can be illustrated that the main advantage of using the dry cooling option is to reduce the amount of water consumption by almost $95 \%$ in both plants. On the other hand, the salt plants with both modes of cooling still consume less water in comparison to those based on thermic oil with $18.19 \%$ for wet mode and $19.67 \%$ for the other one. The water usage in the plants with dry cooling is limited to steam cycle makeup water in addition to mirror cleaning which was taken into consideration as 63 washes per year and $0.7 \mathrm{~L} / \mathrm{m}^{2}$ for every wash [3], and excludes water usage for cooling.

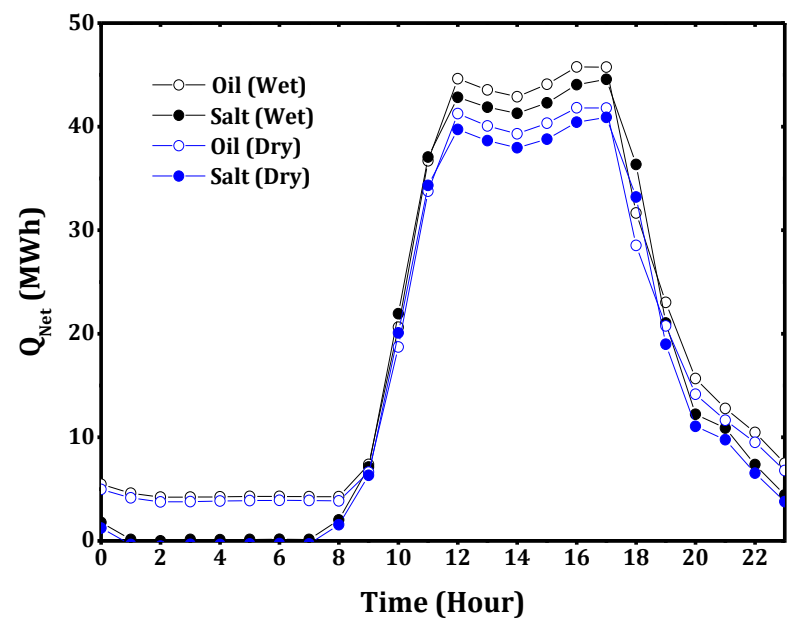

Figure 3. Annual mean hourly net electric power output of the two studied plants by using wet and dry cooling modes.

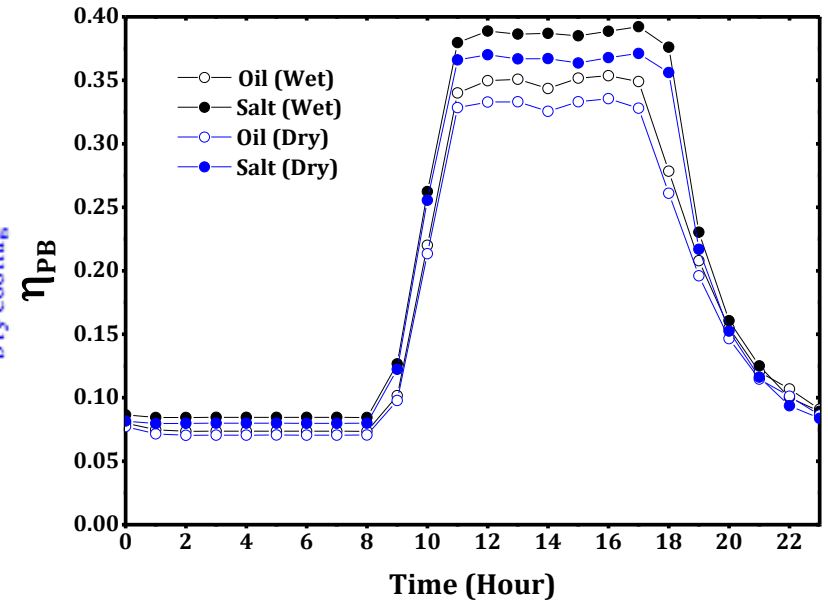

Figure 4. Annual mean hourly power cycle efficiency of the two studied plants by using wet and dry cooling modes.

On the other side, the main disadvantage of using this option is the negative effect on the yields of the studied plants; the efficiencies of the two plants have decreased from $18.64 \%$ (oil plant) and $18.26 \%$ (salt plant) to $17.01 \%$ and $16.56 \%$, respectively. This represents a difference of almost $8.75 \%$ in oil plant, and $9.31 \%$ in plant based on salt technology. This effect is due to the drooping in power cycle efficiencies affected by the decreasing of cooling performances and the increasing of the plants parasitic power consumptions in the power cycles. This decreasing causes a reduction in the annual power generation and capacity factor of about $8.6 \%$ in oil plant and $9.4 \%$ in salt plant. Since the LCOE totally depends on the investment costs and on the annual power generation of the plant, this parameter increases up to 12.66 Cent $\$ / \mathrm{kWh}$ and 10.65 Cent $\$ / \mathrm{kWh}$ for oil and salt configuration, respectively. This means an increase of 9.3 $\%$ and $10.0 \%$ for oil configuration and salt configuration, respectively. While the selection of a solar thermal power plant is contingent upon the identification of sites well suited to the system, the performances of these plants are highly affected by the climatic conditions of sites chosen for the simulation, as they have huge effects on both solar field and cooling system which are the main components of these systems. Therefore, it is highly recommended to simulate the considered plants in other locations with different solar resources, different air temperature variations and different altitudes, to confirm the viability of our study for different sites and conditions. Thereby, in this paper, two other sites (Granada and Dagget) alongside with Bechar have been selected. 
Table 5. The viability analysis of the studied plants in other sites.

\begin{tabular}{|c|c|c|c|c|c|c|}
\hline & \multicolumn{2}{|c|}{$\begin{array}{c}\text { Granada } \\
\left(37.18^{\circ} \mathrm{N}, 3.78\right. \\
\left.{ }^{\circ} \mathrm{W}\right)\end{array}$} & \multicolumn{2}{|c|}{$\begin{array}{c}\text { Dagget } \\
\left(34.86^{\circ} \mathrm{N}, 116.78\right. \\
\left.{ }^{\circ} \mathrm{W}\right)\end{array}$} & \multicolumn{2}{|c|}{$\begin{array}{c}\text { Bechar } \\
\left(31.38^{\circ} \mathrm{N}, 2.15\right. \\
\left.{ }^{\circ} \mathrm{W}\right)\end{array}$} \\
\hline Elevation (m) & \multicolumn{2}{|c|}{599} & \multicolumn{2}{|c|}{588} & \multicolumn{2}{|c|}{722} \\
\hline $\begin{array}{c}\text { Annual DNI } \\
\left(k W h / m^{2}\right)\end{array}$ & \multicolumn{2}{|c|}{2033.3} & \multicolumn{2}{|c|}{2791.4} & \multicolumn{2}{|c|}{2568.9} \\
\hline $\begin{array}{c}\text { Dry bulb } \\
\text { temperature } \\
\left({ }^{\circ} \mathrm{C}\right)\end{array}$ & \multicolumn{2}{|c|}{14.9} & \multicolumn{2}{|c|}{19.8} & \multicolumn{2}{|c|}{21.8} \\
\hline \multicolumn{7}{|l|}{ Oil plant } \\
\hline Type of cooling & Wet & Dry & Wet & Dry & Wet & Dry \\
\hline $\begin{array}{c}\text { Annual power } \\
\text { generation } \\
(G W h)\end{array}$ & 127.82 & 118.68 & 172.83 & 158.79 & 165.74 & 151.26 \\
\hline LCOE $(\phi / k W h)$ & 14.92 & 16.05 & 11.10 & 12.05 & 11.58 & 12.66 \\
\hline $\begin{array}{c}\text { Annual Water } \\
\text { consumption } \\
\left(\mathrm{m}^{3}\right)\end{array}$ & 502,344 & 29,049 & 658,336 & 33,487 & 633,635 & 32,765 \\
\hline \multicolumn{7}{|l|}{ Salt plant } \\
\hline $\begin{array}{c}\text { Annual power } \\
\text { generation } \\
(G W h) \\
\end{array}$ & 107.66 & 99.21 & 148,12 & 135,69 & 147.35 & 133.63 \\
\hline LCOE $(\phi / k W h)$ & 13.13 & 14.22 & 9.60 & 10.45 & 9.68 & 10.65 \\
\hline $\begin{array}{c}\text { Annual Water } \\
\text { consumption } \\
\left(m^{3}\right)\end{array}$ & 407,070 & 23,609 & 519,119 & 26,428 & 518,329 & 26,319 \\
\hline
\end{tabular}

As it can be noted in Table 5, the lowest values of both annual power generation and water consumption are for the salt plant using dry cooling mode installed in Granada (South of Spain), with values of $99.21 \mathrm{GWh}$ and 23,609 $\mathrm{m} 3$, and can take the maximum values for oil plant with the wet cooling option of $172.83 \mathrm{GWh}$ and $658,336 \mathrm{~m} 3$ for Dagget (California, USA). This difference in these two factors is due to the difference in solar resource potentials represented by solar radiation intensity and working hours of the plant. Moreover, plants with higher power generation need more water for cooling system. On the other hand, the salt plant cooled by wet option at Dagget gives the lowest value of LCOE $(9.60 \phi / \mathrm{kWh})$, while the one using oil as the primary HTF, and coupled with dry cooling system at Granada shows the highest value of LCOE (16.05 $\phi / \mathrm{kWh})$.

As we mentioned, and in order to confirm the viability of the obtained results for plants installed in Bechar, it is required to apply the study for other sites. The obtained results show that the drop in the annual power generation between wet and dry cooling options is between $7.7 \%$ and $9.6 \%$ for oil plant, $8.5 \%$ and $10.2 \%$ for salt plant. The same note for annual water consumption as there is a decreasing in water usage in the studied plants between wet and dry of $94.2 \%$ and $94.9 \%$ for both plants (oil and salt). While the LCOE varies between the range of 7.5 $9.32 \phi / \mathrm{kWh}$ for oil plant $8.3-10.0 \phi / \mathrm{kWh}$. This clearly confirms the ability of applying our study to other locations worldwide.

\section{Conclusion}

This paper investigates the effect of deploying dry cooling mode in two different configurations of PTSTPP integrated with TES and FBS; the first configuration uses thermic oil (Therminol VP1) as primary heat transfer fluid in the plant, while the second one is using molten solar salt $\left(60 \% \mathrm{NaNO}_{3}+40 \% \mathrm{KNO}_{3}\right)$. By using the dry cooling option in the two studied configurations, there is a higher drop in the yields of oil plant (a decrease of 8.7 $\%$ ) and salt plant (a decrease of $9.3 \%$ ), in addition to the rise of the LCOE up to $9.3 \%$ and $10.0 \%$ in oil and salt plants, respectively. The obtained results have a big importance to show the effect of working fluids on the cooling system of solar power plants.

It is recommended to preform another study refers to the hybrid mode of cooling before drawing a final conclusion of the effects and techno-economic competiveness of using the three different modes of cooling.

\section{References}

[1] HL Zhang, J Baeyens, J Degrève J, and G Cacères. Concentrated solar power plants: Review and design methodology. Renew Sust Energ Rev, Vol. 22, 2013, pp.466-81.

[2] KS Reddy, KR Kumar. Solar collector field design and viability analysis of stand-alone parabolic trough power plants for Indian conditions, Energ Sustain Dev, Vol. 16(4), 2012, pp.456-70.

[3] TE Boukelia, MS Mecibah, BN Kumar, KS Reddy. Investigation of solar parabolic trough power plants with and without integrated TES (thermal energy storage) and FBS (fuel backup system) using thermic oil and solar salt, Energy, Vol. 88, 2015, pp. 292-303.

[4] TE Boukelia, O Arslan, MS Mecibah. Potential assessment of a parabolic trough solar thermal power plant considering hourly analysis: ANN-based approach, Renew Energy, Vol. 105, 2017, pp 324333.

[5] MJ Montes, A Abánades, JM Martinez-Val. Thermofluidynamic model and comparative analysis of parabolic trough collectors using oil, water/steam, or molten salt as heat transfer fluids, J Sol Energ Eng, Vol. 132(2), 2010, 021001.

[6] A Giostri, M Binotti, M Astolfi, P Silva, E Macchi, and G Manzolini, G. Comparison of different solar plants based on parabolic trough technology, Sol Energy, Vol. 86(5), 2012 pp.1208-21.

[7] A Liqreina, and L Qoaider. Dry cooling of concentrating solar power (CSP) plants, an economic competitive option for the desert regions of the MENA region, Sol. Energy, Vol. 103, 2014, pp.417424.

[8] A Colmenar-Santos, D Borge-Diez, CP Molina, and M Castro-Gil. Water consumption in solar parabolic trough plants: review and analysis of the southern Spain case, Renew. Sustaina. Energy Rev, Vol. 34, 2014, pp.565-577.

[9] M Martín. Optimal annual operation of the dry cooling system of a concentrated solar energy plant in the south of Spain, Energy, Vol. 84, 2015, pp.774782.

[10] H Deng, and RF Boehm. An estimation of the performance limits and improvement of dry cooling on trough solar thermal plants, Appl. Energy, Vol. 88(1), 2011, pp.216-223. 
[11] A Poullikkas, I Hadjipaschalis, G Kourtis. A comparative overview of wet and dry cooling systems for Rankine cycle based CSP plants, Trends in Heat \& Mass Transfer, Vol. 13, 2013, pp.27-50.

[12] L Qoaider, and A Liqreina. Optimization of dry cooled parabolic trough (CSP) plants for the desert regions of the Middle East and North Africa (MENA), Sol. Energy, Vol. 122, 2015, pp.976-985.

[13] SE Trabelsi, R Chargui, L Qoaider, A Liqreina, and A Guizani. Techno-economic performance of concentrating solar power plants under the climatic conditions of the southern region of Tunisia, Energy Convers. Manage, Vol. 119, 2016, pp.203-214.

[14] TE Boukelia, MS Mecibah. Estimation of direct solar irradiance intercepted by a solar concentrator in different modes of tracking (case study: Algeria), Int. J. Amb Energy, Vol. 36 (6), 2015, pp.301-308.

[15] H Price. A parabolic trough solar power plant simulation model, International Solar Energy Conference. Hawaii, USA, 15-18 March 2003.

[16] MJ Wagner, P Gilman. Technical manual for the SAM physical trough model, nrel.gov/docs/fy11osti/51825.pdf. Last accessed 07/06/2017.

[17] MJ Montes, A Abánades, JM Martinez-Val, M Valdés. Solar multiple optimization for a solar-only thermal power plant, using oil as heat transfer fluid in the parabolic trough collectors, Sol Energy, Vol. 83(12), 2009, pp.2165-76

[18] MJ Montes, A Abànades, JM Martînez-Val. Performance of a direct steam generation solar thermal power plant for electricity production as a function of the solar multiple, Sol Energy, Vol. 83(5), 2009, pp.679-89,

[19] T Larraîn, R Escobar, J Vergara. Performance model to assist solar thermal power plant siting in northern Chile based on backup fuel consumption, Renew Energy, Vol. 35(8), 2010, pp.1632-43.

[20] J Dersch, M Geyer, U Herrmann, SA Jones, B Kellyd, R Kistner, W. Ortmanns, R Pitz-Paal, H Price. Trough integration into power plants-a study on the performance and economy of integrated solar combined cycle systems, Energy, Vol. 29(5), 2004, pp.947-959.

[21] NREL. System Advisor Model (SAM) Case study: Andasol-1.

sam.nrel.gov/sites/sam.nrel.gov/files/content/case_stu dies/sam_case_csp_physical_trough_andasol1_2013-1-15.pdf. Last accessed 07.06.2017. 